Review Article

\title{
Treatment of Bone Losses in Revision Total Hip and Knee Arthroplasty Using Trabecular Metal: Current Literature
}

\author{
Umberto Cottino, Federica Rosso, Federico Dettoni, Matteo Bruzzone, \\ Davide Edoardo Bonasia, and Roberto Rossi
}

Department of Orthopedic Surgery, AO Mauriziano, Turati Square 61, 10100 Turin, Italy

Correspondence should be addressed to Umberto Cottino; umberto.cottino@gmail.com

Received 29 April 2016; Accepted 19 July 2016

Academic Editor: Daniela Predoi

Copyright (C) 2016 Umberto Cottino et al. This is an open access article distributed under the Creative Commons Attribution License, which permits unrestricted use, distribution, and reproduction in any medium, provided the original work is properly cited.

Revision Total Knee or Hip Arthroplasty is challenging procedures for surgeons usually characterized by bone loss. There are different options available to treat those bone losses. However, there is still a concern on the stability of bone-implant interface, which is mandatory to achieve good long-term results in prosthetic implants. Recently, porous tantalum has been introduced, with the aim of improving the bone-implant interface fixation and implant primary stability. Different solutions for the treatment of bone defects in both revision Total Knee and Hip Arthroplasty have been proposed. In revision Total Hip Arthroplasty (THA) tantalum shells can be used to treat Paprosky type III defects also, because of their mechanical properties. Similarly, trabecular metal has been proposed in revision Total Knee Arthroplasty (TKA), being considered a viable option to treat severe type 2 or 3 defects. The aim of this paper is to review the mechanical properties and characteristics of tantalum. Furthermore, we will discuss its role in treating bone defects in both revision THA and TKA, as well as the outcome reported in literature.

\section{Introduction}

Osteointegration in orthopedic implants can be compared to bone healing in fractures. Stability at the bone-implant interface is mandatory for implant's success. Excessive micromovements result in fibrous attachment fixation with a collagen structure throughout the porous network [1], while bigger movements can even produce a pseudocapsule [2] surrounding the implant that can lead to early failure. The limits for implant integration have been established in some studies [2,3] showing bone ingrowth for movements smaller than 50 microns, pseudoligamentous healing from 50 to 150 microns, and pseudocapsule formation for movements bigger than 150 microns. However, a small mechanical stimulation at the interface can enhance implant healing in the first phase after surgery.

Another important aspect in implant integration is pore size; recent studies by Bobyn and associates [3] showed the relationship between pore size and bone ingrowth rate. This may be related to different microenvironments present within different sizes pores and their effect on osteogenesis [4].
Traditionally, orthopedic implants have been produced with titanium, stainless steel, and cobalt-chromium (Co$\mathrm{Cr}$ ). However, the limits of these materials in porosity, high elastic modulus, and low frictional characteristics have pushed researchers to develop new materials with better performances. One of the answers to this search is tantalum, firstly introduced by Zimmer (Warsaw, IN). The excellent resistance to erosion-corrosion and high frictional characteristics associated with its bioactivity make tantalum a promising material for orthopedic implants.

\section{Basic Science}

Tantalum is an elemental metal with great characteristics of biocompatibility, corrosion resistance, and a porous geometry. Tantalum has a uniform and continuous structure that allows for greater strength, lower stiffness, higher volumetry porosity, and a higher coefficient of friction compared to other porous metals [5].

Porous tantalum structure is produced by pyrolysis of thermosetting polymer foam; it creates a low-density vitreous 


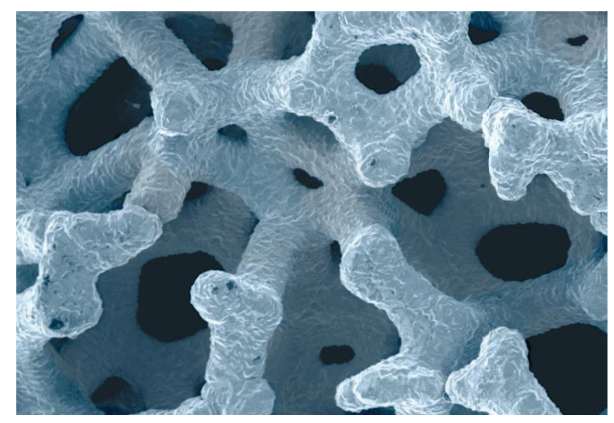

FIGURE 1: Porous structure of the trabecular metal.

carbon skeleton characterized by a repeating dodecahedron that produces a regular structure with interconnecting pores [6]. Tantalum is then deposited on this structure by vaporization or infiltration [7-9]. The production process usually produces coverage that ranges between 40 and $60 \mu \mathrm{m}$ in thickness. However, designers and engineers can vary all parameters of implants regarding shape and pores dimension acting on the skeleton production and metal apposition. For these reasons, tantalum mechanical properties can be changed varying the thickness covering the polymer skeleton (Figure 1).

In common orthopedic application, tantalum pore dimension ranges from 400 to $600 \mu \mathrm{m}$ resulting in a $75 \%$ to $85 \%$ porosity. At the end of the process, $99 \%$ of weight is due to tantalum and $1 \%$ to the skeleton [6]. The porous structure has higher porosity than other materials used in orthopedic implants like sintered beads (30-35\%) and fiber metal (40-50\%) [8], providing a great increase in elasticity and making porous tantalum mechanical properties very close to those of the subchondral bone.

The great number of pores and their dimension positively affects stability of the implant, increasing friction coefficient, up to even three times higher than sintered beads materials [10].

In the long period, primary stability is enhanced by tantalum bioactivity that produces a stable oxide component $\left(\mathrm{Ta}_{2} \mathrm{O}_{5}\right)$ on the surface forming a bone-like apatite layer [11]. These characteristics represent a great improvement compared to conventional materials. Classically, implants' bioactive coatings applied to the surface of the implant grant bone integration. The effect is to bond bone; however, they showed to degrade over time and debond from the implant surface with possible loosening.

Tantalum morphology provides a scaffold for bone growth and osteoblast interaction $[2,7,12,13]$, producing a bone ingrowth that has been measured to be 0.2 to $2 \mathrm{~mm}$ in 4 weeks [12]. For these reasons, pullout tests demonstrated that tantalum could resist doubled shears forces, compared to conventional materials (18.5 MPa versus 9.3 MPa of the CoCr sintered beads) $[3,7,12]$. Complete incorporation into the bone is usually achieved around 16 weeks after implant and no major variations can be observed at one year [7].

The association of great friction rate and the subsequent osteointegration makes tantalum the perfect material for bone loss managing and defect filling.
In addition, tantalum is relatively inert in vivo and can be compared to titanium; by the way, tantalum can produce occasional macrophage reaction at the implant-tissue interface [14]. At our knowledge, there are no studies reporting inflammatory reaction to tantalum.

\section{Treatment of Bone Deficiency in Revision Total Hip Arthroplasty}

The number of Total Hip Arthroplasties (THA) is increasing, as well as life expectancy. Consequently, the number and complexity of revision THA continue to increase, with a further increase expected in 2030 of $137 \%$ compared to 2005 [15]. Revision THA are usually challenging for surgeons, particularly on the acetabular side, which is more commonly characterized by bone loss. In socket revisions, the surgeon has to manage bone defects and provide a stable construct; in these cases an accurate preoperative planning is mandatory to achieve good results [16].

Different classification systems have been used for acetabular defects to describe the severity of bone losses. Paprosky et al. developed a classification evaluating the acetabular defect type, size, and location, pointing at the appropriate reconstructive options' selection. The classification is based on four radiographic measures obtained through an anteroposterior radiograph of the pelvis: (1) superior hip center migration, (2) ischial osteolysis, (3) position of the implant relative to the Kohler (ilioischial) line, and (4) teardrop osteolysis (Table 1) [17].

Bone losses are consequently classified depending on the support for the new acetabular cup of the acetabulum: completely supportive (type I), partially supportive (type II), or unsupportive (type III). The reconstruction options for acetabular revision include hemispherical cementless cup, jumbo cup, structural or morselized allograft, custom or triflanged implants, and antiprotrusio cage [18]. Trabecular metal implant or augments can be useful to treat major bone defects, allowing for increased biological fixation, primary stabilization, and easier surgical technique, also when compared to structural allograft.

3.1. Reconstructive Options Using Trabecular Metal. Highly porous metal components are popular options for both primary and revision THA. Conversely to titanium components, which require at least $50 \%$ of supporting bone stock, these cups can be used also in Paprosky type III defects, because of their mechanical properties $[18,19]$. Using trabecular metal cups allows for good osteointegration and primary stability of the system [20]. There are two types of tantalum cups: with incorporated locking mechanism for the polyethylene insert or predisposed for cementation of the polyethylene insert. The second option allows a greater malleability of implant by positioning it in the area of the defect not considering its position and orientation that can be compensated by reorienting the insert at the time of cementation [18]. When less than $50 \%$ of bone stock is available, structural allograft or metal augments may be required to allow stability of the cup. Porous metal augments can be assembled intraoperatively acting as 
TABle 1: The Paprosky classification.

\begin{tabular}{lcccc}
\hline Defect type & Superior hip center migration & Ischial osteolysis & Kohler line & Teardrop \\
\hline I & Minimal & None & Intact & Intact \\
IIA & Mild & Mild & Intact & Intact \\
IIB & Moderate & Mild & Intact & Intact \\
IIC & Mild & Mild & Disrupted & Moderate lysis \\
IIIA & Severe & Moderate & Intact & Moderate lysis \\
IIIB & Severe & Severe & Disrupted & Severe lysis \\
\hline
\end{tabular}

a structural allograft. The surgical technique includes securing the augments to the pelvis with multiple screws and then securing the revision shell to the augment with bone cement. The shell is then secured to the pelvis with multiple screws $[6,21,22]$. When the augment is secured to the acetabular shell, the surface area of the cup available for bone ingrowth can be raised up to 30 or $40 \%$ of the surface more than the implant with no augments [16]. However, care should be used implanting trabecular metal cups: Springer et al. detected 7 transverse acetabular fractures in a series of 37 trabecular metal cup revisions; all fractures likely occurred intraoperatively [23].

Trabecular metal augments can be also useful for type III defect; in presence of massive contained or uncontained defects involving more than $50 \%$ of the acetabulum, a protective cage may be necessary. Particularly, if morselized or structural grafts are used and the necessary amount of contact is not achievable, the bone graft should be protected by a cage [24]. These cages have different advantages: they can be used as a template for bone stock restoration and they allow placing the hip center in an anatomic position independently by the cage position. However, the surgical technique is demanding and the cages do not allow for bone integration [24]. Different authors reported poor results using cages, with a high failure rate, particularly in those cases with insufficient column or superior dome bone stock to support the cage and the graft or in case of pelvic discontinuity $[16,25,26]$. For this reason, different authors proposed using trabecular metal in these cases as well. Some authors proposed to use a "cup-cage" system. The trabecular metal cup, because of its properties, allows for a better healing environment for the graft. If an adequate amount of bone is not available, a cage can protect the cup. The cage protects the cup until bone graft remodeling is complete, and then the stress leaves off the cage and is transferred on the trabecular metal cup $[16,24,27,28]$.

When the anterior and posterior walls are insufficient in a pelvic discontinuity, trabecular metal cups and augments can be used to restore acetabular ring integrity. The augments are placed in the inferior and superior aspect of the acetabular defect, secured to the bone with screws, and the cup is then inserted press-fit into the contained bone defect of host bone. To provide rigid fixation, multiple screws can be placed in both the superior and inferior hemipelvis. This construct can be used as an internal plate to stabilize discontinuity $[25,28,29]$.

3.2. Clinical Outcomes. Different studies focused on clinical outcomes of trabecular metal constructs in revision THA (Table 2). Given that most of these studies are characterized by short-term follow-up or small population, good clinical and radiological outcomes are reported, despite a considerable complication rate related to the complexity of the surgery [19-21, 25, 28-41].

Van Kleunen et al. in 2009 [42] reported 90 patients with Paprosky type 2 or more acetabular bone defects, treated with revision shell associated with metal augments. There were 8 cases of infection and one revision for dislocation. No revisions for aseptic loosening were detected. The authors concluded that revision shells associated with metal augments are a viable option to treat moderate to severe bone losses in acetabular revision. Jafari et al. [43] compared the outcomes of titanium and tantalum cup in 283 hip revisions with mixed acetabular bone defects; the authors concluded that there was a higher failure rate in massive bone deficiency for titanium cups compared to tantalum cups, which showed radiographical better fixation. Similarly, Fernández-Fairen et al. [44] evaluated 263 patients treated with monoblock or revision tantalum shell, with $85.9 \%$ subjective satisfaction, and no aseptic loosening at 73-month follow-up. Skyttä et al. [45] evaluated 827 patients treated with trabecular metal shell in revision hip arthroplasty with patterns of bone loss, representing the biggest population described in literature. The authors observed a $92 \%$ overall survivorship at 3-year follow-up, with $2 \%$ of aseptic loosening. Furthermore, each additional year in age decreased the risk of revision by $2.4 \%$. Recently, Long et al. [46] evaluated 599 revision shells at a minimum of 24 months of follow-up reporting $7.8 \%$ of reoperation, with $2.3 \%$ of removed cup but without any case of aseptic loosening.

In the recent years, some authors described their experience using cup-cage constructs. Abolghasemian et al. [47] evaluated 26 patients affected by pelvic discontinuity and treated with cup-cage construct and 16 patients treated using standard cages. The authors reported a reduced complication and revision rate in the cup-cage group, with a higher pelvic discontinuity healing-rate compared to the standard cages. Recently, Amenabar et al. [48] described their results on 64 patients affected by Paprosky types 3 and 4 defects with $61 \%$ of pelvic discontinuity and treated using cup-cage constructs. The 5- and 10-year cumulative survivorship was, respectively, 93\% and $85 \%$. The authors concluded that cupcage constructs are a viable option in the treatment of major acetabular bone losses.

\section{Treatment of Bone Deficiency in Revision Total Knee Arthroplasty}

Similar to THA, also the number of revision Total Knee Arthroplasties (TKA) is increasing [15]. Revision TKA can 
TABLE 2: Results for revision THA using porous tantalum acetabular components (THA: Total Hip Arthroplasty, N/A: not reported).

\begin{tabular}{|c|c|c|c|c|c|c|c|}
\hline Author & Year & $\begin{array}{l}\text { Number of } \\
\text { cases }(\mathrm{F} / \mathrm{M})\end{array}$ & $\begin{array}{l}\text { Average age } \\
\text { (SD) }\end{array}$ & $\begin{array}{l}\text { The Paprosky } \\
\text { classification of } \\
\text { bone defect }\end{array}$ & $\begin{array}{l}\text { Type of } \\
\text { implant }\end{array}$ & $\begin{array}{l}\text { Follow-up } \\
\text { months } \\
\text { (SD) }\end{array}$ & Outcome \\
\hline Nehme et al. [30] & 2004 & 16 & N/A & 2 and 3 & $\begin{array}{l}\text { Revision shell } \\
\text { and modular } \\
\text { augments }\end{array}$ & 31.9 & $\begin{array}{l}\text { No implant had evidence of } \\
\text { migration or loosening } \\
\text { Good clinical and } \\
\text { radiological outcomes at early } \\
\text { follow-up; } 1 \text { revision for pelvic } \\
\text { discontinuity, } 1 \text { dislocation, } 1 \\
\text { sciatic nerve palsy }\end{array}$ \\
\hline Unger et al. [31] & 2005 & 60 & N/A & N/A & $\begin{array}{l}\text { Tantalum cup } \\
\text { with screws }\end{array}$ & 42 & $\begin{array}{l}7 \text { cases of dislocation and } 1 \\
\text { case of aseptic loosening }\end{array}$ \\
\hline Paprosky et al. [25] & 2005 & $\begin{array}{l}12 \text { (versus } 12 \\
\text { patients } \\
\text { reconstructed } \\
\text { with cage) }\end{array}$ & 61 & $\begin{array}{c}3 \text { (all pelvic } \\
\text { discontinuity) }\end{array}$ & $\begin{array}{l}\text { Trabecular } \\
\text { metal cup } \\
\text { with or } \\
\text { without } \\
\text { augments }\end{array}$ & 25.2 & $\begin{array}{l}11 \text { patients with no or } \\
\text { moderate pain in tantalum } \\
\text { group versus } 8 \text { patients in } \\
\text { cage group; } 1 \text { aseptic } \\
\text { loosening case in the } \\
\text { tantalum group versus } 8 \text { cases } \\
\text { in the cage group }\end{array}$ \\
\hline $\begin{array}{l}\text { Sporer and } \\
\text { Paprosky [32] }\end{array}$ & 2006 & 28 & 64 & $3 \mathrm{~A}$ & $\begin{array}{l}\text { Trabecular } \\
\text { metal cup } \\
\text { plus superior } \\
\text { augment }\end{array}$ & 37.2 & $\begin{array}{l}\text { All hips radiographically } \\
\text { stable; no revision; good } \\
\text { clinical outcome }\end{array}$ \\
\hline $\begin{array}{l}\text { Sporer and } \\
\text { Paprosky [33] }\end{array}$ & 2006 & 13 & N/A & $\begin{array}{c}\text { 3B (pelvic } \\
\text { discontinuity) }\end{array}$ & $\begin{array}{l}\text { Revision shell } \\
\text { with/without } \\
\text { augments }\end{array}$ & 31.2 & $\begin{array}{l}1 \text { possible radiographic } \\
\text { loosening; no revision surgery } \\
\text { Reliable and reproducible } \\
\text { short-term results in pelvic } \\
\text { discontinuity }\end{array}$ \\
\hline $\begin{array}{l}\text { Weeden and } \\
\text { Schmidt [29] }\end{array}$ & 2007 & 43 & N/A & $\begin{array}{c}\text { 3A, 3B (10 pelvic } \\
\text { discontinuity } \\
\text { cases) }\end{array}$ & $\begin{array}{l}\text { Trabecular } \\
\text { metal cup } \\
\text { with or } \\
\text { without } \\
\text { augments } \\
\end{array}$ & 33.6 & $\begin{array}{l}1 \text { septic loosening case } \\
98 \% \text { success rate; excellent } \\
\text { option in revision TKA }\end{array}$ \\
\hline Malkani et al. [34] & 2009 & $25(16 / 9)$ & $71.7(10.5)$ & 2 or 3 & $\begin{array}{l}\text { Revision shell } \\
\text { with/without } \\
\text { augments }\end{array}$ & 39 (11) & $\begin{array}{l}21 \text { well-fixed and functioning } \\
\text { implants, with ingrowth along } \\
\text { the tantalum surface; no } \\
\text { dislocation or aseptic } \\
\text { loosening }\end{array}$ \\
\hline Flecher et al. [35] & 2008 & 23 & 58.2 & $\begin{array}{l}\text { 3A, } 3 \mathrm{~B} \text { (8 pelvic } \\
\text { discontinuity } \\
\text { cases) }\end{array}$ & $\begin{array}{l}\text { Revision shell } \\
\text { with or } \\
\text { without } \\
\text { augments }\end{array}$ & 35 & $\begin{array}{l}\text { No mechanical failure } \\
\text { Suitable options for type III } \\
\text { defects and alternative } \\
\text { options to bone graft and } \\
\text { cages }\end{array}$ \\
\hline $\begin{array}{l}\text { Van Kleunen et al. } \\
\text { [42] }\end{array}$ & 2009 & $90(50 / 40)$ & 59 & Minimum 2A & $\begin{array}{l}\text { Revision shell } \\
\text { with/without } \\
\text { augments; } 2 \\
\text { antiprotrusio } \\
\text { cage cases }\end{array}$ & 45 & $\begin{array}{l}8 \text { revisions for infection and } 1 \\
\text { case for instability; no } \\
\text { revision for aseptic loosening }\end{array}$ \\
\hline Siegmeth et al. [21] & 2009 & $34(19 / 15)$ & 64 & $\begin{array}{l}\text { 2, } 3 \text { ( } 2 \text { pelvic } \\
\text { discontinuity } \\
\text { cases })\end{array}$ & $\begin{array}{l}\text { Trabecular } \\
\text { metal shell } \\
\text { with } \\
\text { augments } \\
\text { and screws }\end{array}$ & 34 & $\begin{array}{l}2 \text { aseptic failures; good } \\
\text { clinical and radiological } \\
\text { outcomes at short-term } \\
\text { follow-up }\end{array}$ \\
\hline Lakstein et al. [36] & 2009 & $53(24 / 29)$ & 63 & $\begin{array}{l}\text { Less than } 50 \% \text { of } \\
\text { contact }\end{array}$ & $\begin{array}{l}\text { Trabecular } \\
\text { metal cups }\end{array}$ & 45 & $\begin{array}{l}2 \text { failed cup cases ( } 4 \% \text { ); other } \\
2 \text { cups with radiological signs } \\
\text { of aseptic loosening; } 4 \\
\text { dislocation cases, } 1 \text { sciatic } \\
\text { nerve palsy case }\end{array}$ \\
\hline
\end{tabular}


TABle 2: Continued.

\begin{tabular}{|c|c|c|c|c|c|c|c|}
\hline Author & Year & $\begin{array}{l}\text { Number of } \\
\text { cases }(F / M)\end{array}$ & $\begin{array}{l}\text { Average age } \\
\text { (SD) }\end{array}$ & $\begin{array}{l}\text { The Paprosky } \\
\text { classification of } \\
\text { bone defect }\end{array}$ & $\begin{array}{l}\text { Type of } \\
\text { implant }\end{array}$ & $\begin{array}{l}\text { Follow-up } \\
\text { months } \\
\text { (SD) }\end{array}$ & Outcome \\
\hline Jafari et al. [43] & 2010 & $283(128 / 155)$ & 69 & Mixed & $\begin{array}{l}\text { Tantalum cup } \\
\text { (79) versus } \\
\text { titanium cup } \\
\quad(207)\end{array}$ & 43.6 & $\begin{array}{l}\text { Failure rate: titanium } 8 \% \text {, } \\
\text { tantalum } 6 \% \\
\text { Higher failure rate in } \\
\text { massive bone deficiency for } \\
\text { titanium cups } \\
\text { Radiographically better } \\
\text { fixation for tantalum cups }\end{array}$ \\
\hline Flecher et al. [37] & 2010 & $71(41 / 30)$ & 60 & Mixed & $\begin{array}{l}\text { Tantalum cup } \\
\text { with/without } \\
\text { augments }\end{array}$ & 48 & $\begin{array}{l}\text { No radiolucent lines, } 3 \\
\text { revisions for instability } \\
\text { Good restoration of } \\
\text { rotation center of the hip }\end{array}$ \\
\hline $\begin{array}{l}\text { Fernández-Fairen } \\
\text { et al. [44] }\end{array}$ & 2010 & $263(150 / 113)$ & 69.5 & Mixed & $\begin{array}{l}\text { Monoblock } \\
\text { or revision } \\
\text { shell with or } \\
\text { without } \\
\text { augments }\end{array}$ & 73.6 & $\begin{array}{l}85.9 \% \text { of satisfied patients } \\
\text { All cups were stable, no } \\
\text { revision, no radiolucent } \\
\text { lines }\end{array}$ \\
\hline $\begin{array}{l}\text { Lachiewicz and } \\
\text { Soileau [19] }\end{array}$ & 2010 & $37(19 / 18)$ & 65.1 & 3 & $\begin{array}{l}\text { Tantalum } \\
\text { cups and } \\
\text { augments }\end{array}$ & 39.6 & $\begin{array}{l}\text { 97\% of well-fixed } \\
\text { component; } 1 \text { mechanical } \\
\text { failure; } 7 \text { revisions } \\
\text { (dislocation, infection, } \\
\text { periprosthetic fracture) }\end{array}$ \\
\hline $\begin{array}{l}\text { Ballester Alfaro } \\
\text { and Sueiro } \\
\text { Fernandez [27] }\end{array}$ & 2010 & $19(12 / 7)$ & 63 & $3 \mathrm{~A}$ and $3 \mathrm{~B}$ & $\begin{array}{l}\text { Cup-cage } \\
\text { constructs }\end{array}$ & 26 & $\begin{array}{l}\text { No mechanical failures } \\
\text { Buttress tantalum } \\
\text { augments, with cup-cage } \\
\text { construct for severe bone } \\
\text { defects can be a viable } \\
\text { option }\end{array}$ \\
\hline Skyttä et al. [45] & 2011 & $827(522 / 447)$ & 69.1 & N/A & $\begin{array}{l}\text { Trabecular } \\
\text { metal } \\
\text { revision shell }\end{array}$ & 36 & $\begin{array}{l}\text { The 3-year overall } \\
\text { survivorship was } 92 \% ; 2 \% \\
\text { revision for aseptic } \\
\text { loosening; each additional } \\
\text { year in age decreased the } \\
\text { risk of revision by } 2.4 \%\end{array}$ \\
\hline Davies et al. [38] & 2011 & $46(24 / 22)$ & 66.7 & $2 \mathrm{C}$ or 3 & $\begin{array}{l}\text { Tantalum } \\
\text { cups with or } \\
\text { without } \\
\text { augments or } \\
\text { buttress plate }\end{array}$ & 50 & $\begin{array}{l}1 \text { infection, } 2 \text { dislocations, } \\
\text { and } 1 \text { arterial bleeding } \\
\text { Good clinical outcomes; no } \\
\text { loosening }\end{array}$ \\
\hline $\begin{array}{l}\text { Del Gaizo et al. } \\
\text { [39] }\end{array}$ & 2012 & 36 & 60 & $3 \mathrm{~A}$ & $\begin{array}{l}\text { Tantalum } \\
\text { cups and } \\
\text { augments }\end{array}$ & 26 & $\begin{array}{l}\text { One aseptic loosening; } 7 \\
\text { revisions (dislocation, } \\
\text { infection, periprosthetic } \\
\text { fracture) } \\
\text { Reasonable function with } \\
\text { low rates of loosening at } \\
\text { midterm follow-up }\end{array}$ \\
\hline Gehrke et al. [40] & 2013 & $46(28 / 18)$ & 65 & $2 \mathrm{~B}, 3 \mathrm{~A}$ & $\begin{array}{l}\text { Tantalum } \\
\text { cups and } \\
\text { augments }\end{array}$ & 46 & $\begin{array}{l}4 \text { hips of dislocation; } 2 \\
\text { revisions because of early } \\
\text { loosening; tantalum } \\
\text { implants were } \\
\text { radiographically stable and } \\
\text { osteointegrated }\end{array}$ \\
\hline Batuyong et al. [28] & 2014 & 24 & 67 & 3,4 & $\begin{array}{l}\text { Trabecular } \\
\text { metal shell } \\
\text { with/without } \\
\text { augments } \\
\text { and cage }\end{array}$ & 37 & $\begin{array}{l}92 \% \text { osteointegration; } 2 \\
\text { failures for septic loosening }\end{array}$ \\
\hline
\end{tabular}


TABLE 2: Continued.

\begin{tabular}{|c|c|c|c|c|c|c|c|}
\hline Author & Year & $\begin{array}{l}\text { Number of } \\
\text { cases }(F / M)\end{array}$ & $\begin{array}{l}\text { Average age } \\
\text { (SD) }\end{array}$ & $\begin{array}{l}\text { The Paprosky } \\
\text { classification of } \\
\text { bone defect }\end{array}$ & $\begin{array}{l}\text { Type of } \\
\text { implant }\end{array}$ & $\begin{array}{l}\text { Follow-up } \\
\text { months } \\
(\mathrm{SD})\end{array}$ & Outcome \\
\hline Moličnik et al. [20] & 2014 & $25(11 / 14)$ & 69.7 & Minimum 2A & $\begin{array}{c}\text { Trabecular } \\
\text { metal shell } \\
\text { with/without } \\
\text { augments }\end{array}$ & 20.9 & $\begin{array}{l}\text { No aseptic loosening; } 1 \\
\text { revision for traumatic } \\
\text { dislocation; it is a suitable } \\
\text { option in revision THA } \\
\text { with good short-term } \\
\text { outcomes }\end{array}$ \\
\hline $\begin{array}{l}\text { Abolghasemian et } \\
\text { al. [47] }\end{array}$ & 2014 & $\begin{array}{c}26(20 / 4) \\
\text { versus } 19 \\
(18 / 1) \text { treated } \\
\text { with cage }\end{array}$ & 65 & $\begin{array}{c}\text { All pelvic } \\
\text { discontinuity }\end{array}$ & $\begin{array}{c}\text { Cup-cage } \\
\text { construct } \\
\text { versus cage }\end{array}$ & 82 & $\begin{array}{l}4 \text { major complications in } \\
\text { cup-cage group versus } 9 \text { in } \\
\text { the cage group; all } \\
\text { discontinuity healed in } \\
\text { cup-cage group, only } 3 \text { in } \\
\text { the cage group; } 3 \text { early } \\
\text { migrations in the cup-cage } \\
\text { group }\end{array}$ \\
\hline Long et al. [46] & 2015 & $599(345 / 254)$ & 65.5 & N/A & Revision shell & 24 & $\begin{array}{l}7.8 \% \text { of reoperations; } 2.3 \% \\
\text { of cup removal ( } 12 / 14 \text { for } \\
\text { septic loosening); no } \\
\text { revision for aseptic } \\
\text { loosening }\end{array}$ \\
\hline $\begin{array}{l}\text { Amenabar et al. } \\
\text { [48] }\end{array}$ & 2016 & $64(50 / 14)$ & 66 & $\begin{array}{c}3 \text { and } 4(61 \% \text { of } \\
\text { pelvic } \\
\text { discontinuity) }\end{array}$ & $\begin{array}{l}\text { Cup-cage } \\
\text { construct }\end{array}$ & 74 & $\begin{array}{l}93 \% \text { and } 85 \% \text { of, } \\
\text { respectively, } 5 \text { and } 10 \text { years } \\
\text { of cumulative survivorship; } \\
\text { it is a suitable option in } \\
\text { pelvic discontinuity }\end{array}$ \\
\hline
\end{tabular}

be a demanding procedure for both the patients and the surgeons. Usually, the surgeons have to deal with bone losses, ligamentous deficiencies, and loss of adequate fixation. Engh and Ammeen [49] proposed the "Anderson Orthopaedic Research Institute" (AORI) classification of bone defects. Femoral and tibial bone losses are classified into three types, according to the extent and severity of the defect. Type 1 defects are characterized by intact metaphyseal bone stock, without subsidence of the components nor osteolysis. In type 2 defects the metaphyseal bone is damaged in one (A) or both (B) condyles. On the femoral side these defects are usually distal to the epicondyles, and on the tibial side they are up to or below the fibular head. Type 3 defects include major bone losses, generally associated with ligamentous insufficiency, proximal to the epicondyle in the femur and distal to the tibial tuberosity at the tibia.

Furthermore, bone defects can be divided into cavitary or segmental, depending on the status of the cortical ring surrounding the defect [50]. The bone defects should be reclassified after removal of the components, as their amount usually increases much during surgery. A minimum defect theoretically involves less than $50 \%$ of a single condyle, with a depth of less than $5 \mathrm{~mm}$. A moderate defect involves $50 \%$ to $70 \%$ of a single condyle with a depth of 5 to $10 \mathrm{~mm}$. An extensive defect involves more than $70 \%$ of a condyle with a depth over $10 \mathrm{~mm}$. Finally, a massive cavitary defect is characterized by the total disruption of one or both femoral condyles and can be either associated with an intact cortical rim or not [50].
In this scenario, obtaining a stable fixation of the revision implant is mandatory. Morgan-Jones et al. [52] recently defined the "zonal fixation" concept. The femur and tibia can be divided into three zones: the joint surface or epiphysis, the metaphysis, and the diaphysis. The authors suggest that solid fixation should be achieved in at least two out of the three zones.

4.1. Surgical Options Using Trabecular Metal and Techniques. Available options to treat bone defects are bone cement, autograft, morselized or structural allograft, metal augments, cones, and sleeves [53]. The chosen technique depends on patient age, life expectancy, bone loss classification, need for diaphyseal fixation, and ligamentous insufficiency. Radnay and Scuderi [51] developed an algorithm to deal with bone losses (Table 3). If the defects are small and cavitary and involve less than $1 / 4$ of the cortical rim, they can be filled using cement or bone grafts. Conversely, if the defect involves more than $1 / 4$ of the cortical rim or it is segmental, metal augments must be considered. Metal augments should also be considered if more than $40 \%$ of the implant interface is not supported by host bone. Metal augments resulted to be particularly useful in 5 to $10 \mathrm{~mm}$ type 2 defects. Major bone defects, particularly type 3 defects, are the most demanding to treat. Allograft, metal augment, hinged implant, and long stems may turn out to be useful in obtaining adequate fixation and stability in these cases. Trabecular metal is indicated in treating major bone loss, providing adequate fixation and stability. Trabecular metal has been proposed in revision TKA 
TABLE 3: Radnay's algorithm for bone loss treatment in revision TKA [51].

\begin{tabular}{lcc}
\hline Type 1 defects & Type 2 defects & Type 3 defects \\
\hline Cement & Defects $<5 \mathrm{~mm}$ : cement & Unicondylar: metal augments \\
Morselized bone graft & Defects $5-10 \mathrm{~mm}$ : metal augment & $\begin{array}{c}\text { Bicondylar: metal augments, tantalum cones, structural } \\
\text { allograft, hinge/tumor prosthesis }\end{array}$ \\
Metal augment & Defects $>10 \mathrm{~mm}$ : structural allograft or metal augments & \\
\hline
\end{tabular}

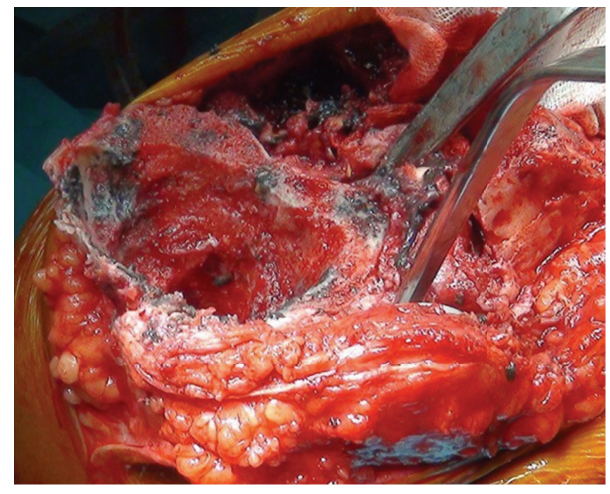

FIgURE 2: Tibial bone defect at the end of the preparation for implanting a tantalum cone.

because of its properties, such as increased osteointegration and structural stability. Tantalum cones can be a viable option to treat severe type 2 or 3 bone defects and can be used in association with tantalum augments to increase primary fixation [50]. Stepped cones are also available when the bone defect is greater on one side of the tibial plateau compared to the other [51].

4.1.1. Tantalum Cones' Surgical Technique. Bony surfaces have to be completely debrided from necrotic bone and residual cement, and the bone defect is sized. The residual bone has to be prepared for the tantalum cones. Dedicated instrumentation with trial is available. Once the surgeon has chosen the size of the cone, the defect is prepared using high speed burr, to reach the shape of the cone (Figure 2). On the femoral side, dedicated rasp can be used, but carefully in order to avoid fracturing the impacted bone (Figure 3). Both on the tibial and on femoral side, care should be taken not to overresect the bone, because the cones have to be inserted with a tight press-fit. If there is still a defect between the cone and the host bone, it can be filled using morselized grafting (Figure 4). Once the cone is impacted into the host bone, the final tibial or femoral component is cemented into the cone. Association of a tibial or femoral stem is useful to guarantee better stability and fixation of the construct (Figure 5) [50, 51, 54, 55].

Trabecular metal has also been proposed to treat severe patellar bone defect in revision TKA. Porous tantalum patellar component allows for implantation of a polyethylene patellar component. However, using a patellar tantalum component as an alternative to bone grafting requires sufficient

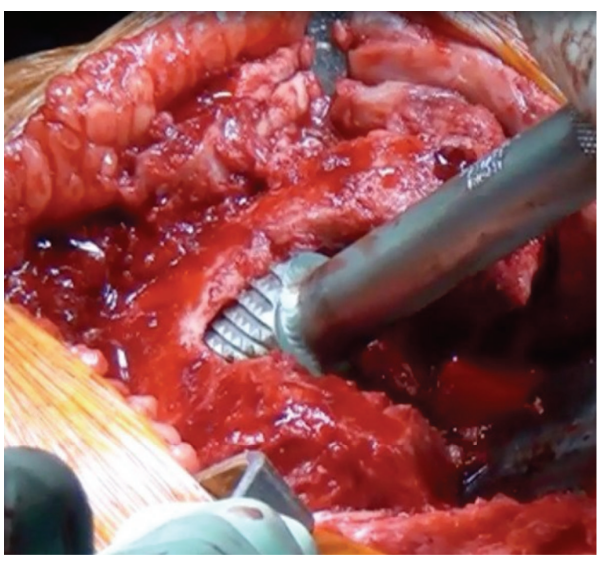

FIGURE 3: Preparation with rasp for a femoral tantalum cone.

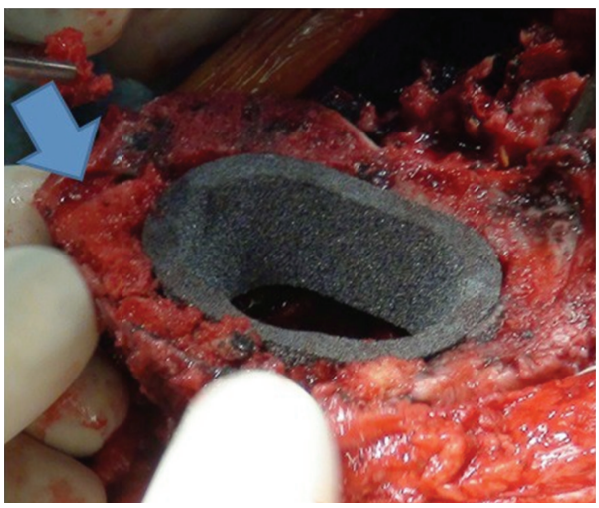

FIGURE 4: Tibial tantalum cone implanted. The blue arrow shows the filling of the remaining defect with morselized bone.

blood supply to allow for the incorporation of the new component in the residual patellar bone [56].

4.2. Clinical Outcomes. Considering the recent introduction of tantalum materials, only short-term follow-up studies are available (Table 4) [54, 57-63].

Most of these studies reported good clinical and radiological outcomes with low revision rate for aseptic loosening $(0.9 \%)$, despite an increased revision rate for infection $(2.2 \%)$ [55].

Howard et al., in 2011 [66], reported 24 femoral cones used to fill type 2 or 3 femoral bone defects. The authors reported a high reoperation rate, but without any aseptic loosening or mobilization of the tantalum cone at short-term 
TABLE 4: Results for revision TKA or patellar replacement using porous tantalum components (TKA: Total Knee Arthroplasty, N/A: not reported).

\begin{tabular}{|c|c|c|c|c|c|c|c|}
\hline Author & Year & $\begin{array}{l}\text { Number of cases } \\
\text { (femoral/tibial) }\end{array}$ & $\begin{array}{l}\text { Average } \\
\text { age } \\
(\mathrm{SD})\end{array}$ & $\begin{array}{l}\text { Bone defect } \\
\text { classification } \\
(\text { AORI })\end{array}$ & $\begin{array}{l}\text { Type of } \\
\text { implant }\end{array}$ & $\begin{array}{l}\text { Follow-up } \\
\text { months } \\
\text { (SD) }\end{array}$ & Outcomes \\
\hline Nelson et al. [64] & 2003 & 20 & 70 & N/A & $\begin{array}{c}\text { Porous } \\
\text { tantalum } \\
(\mathrm{PT}) \text { patellar } \\
\text { components }\end{array}$ & 23 & $\begin{array}{l}\text { Good or excellent results in } \\
17 \text { patients; } 3 \text { polar patellar } \\
\text { fractures postoperatively; } \\
\text { no sign of loosening }\end{array}$ \\
\hline $\begin{array}{l}\text { Nasser and Poggie } \\
{[65]}\end{array}$ & 2004 & 11 & 66 & N/A & $\begin{array}{c}\text { Porous } \\
\text { tantalum } \\
(\mathrm{PT}) \text { patellar } \\
\text { components }\end{array}$ & 32 & $\begin{array}{l}\text { All implants stable, high } \\
\text { patients' satisfaction }\end{array}$ \\
\hline Meneghini et al. [57] & 2008 & 15 & 68.1 & Types 2 and 3 & $\begin{array}{l}\text { Femoral and } \\
\text { tibial } \\
\text { tantalum } \\
\text { cones } \\
\end{array}$ & 34 & $\begin{array}{l}\text { All cones were } \\
\text { osteointegrated at the } \\
\text { follow-up; no loosening or } \\
\text { migration }\end{array}$ \\
\hline Long and Scuderi [58] & 2009 & 16 (all tibial) & 66.1 & $\begin{array}{l}2 \mathrm{~T} 2 \mathrm{~A}, 3 \mathrm{~T} 2 \mathrm{~B}, 4 \\
\mathrm{~T} 3 \mathrm{~A}, 7 \mathrm{~T} 3 \mathrm{~B} \text { tibial } \\
\text { bone defects }\end{array}$ & $\begin{array}{l}\text { Tantalum } \\
\text { tibial cones }\end{array}$ & 31 & $\begin{array}{l}2 \text { cases of reinfections; in } \\
\text { the remaining cases no } \\
\text { reoperations and no signs } \\
\text { of loosening; good } \\
\text { short-term results were } \\
\text { achieved in complex } \\
\text { revisions, with these new } \\
\text { cones }\end{array}$ \\
\hline Howard et al. [66] & 2011 & 24 (all femoral) & 64 & Types 2 and 3 & $\begin{array}{l}\text { Femoral } \\
\text { tantalum } \\
\text { cones }\end{array}$ & 33 & $\begin{array}{l}21 \% \text { required } \\
\text { subsequent } \\
\text { surgery (no aseptic } \\
\text { loosening); all femoral } \\
\text { cones appeared well-fixed } \\
\text { radiographically, with no } \\
\text { evidence of complications } \\
\text { related to the cone }\end{array}$ \\
\hline Lachiewicz et al. [59] & 2012 & $33(9 / 24)$ & 64.6 & N/A & $\begin{array}{l}\text { Femoral or } \\
\text { tibial cone }\end{array}$ & 39.6 & $\begin{array}{l}2 \text { cones removed for } \\
\text { infection at } 12 \text { months, } 1 \\
\text { revision for loosening } \\
\text { Metaphyseal fixation with } \\
\text { tantalum cones can be } \\
\text { achieved }\end{array}$ \\
\hline Kamath et al. [56] & 2012 & 23 & 62 & N/A & $\begin{array}{c}\text { Porous } \\
\text { tantalum } \\
(\mathrm{PT}) \text { patellar } \\
\text { components }\end{array}$ & 92.4 & $\begin{array}{l}\text { All patellae had less than } \\
10 \text { mm residual thickness; } \\
\text { in } 2 \text { cases direct sutures to } \\
\text { the tendons; } 4 \text { revision } \\
\text { surgeries; } 83 \% \text { of } \\
\text { survivorship; failures were } \\
\text { associated with avascular } \\
\text { necrosis of the residual } \\
\text { bone and direct suture to } \\
\text { the extensor apparatus }\end{array}$ \\
\hline $\begin{array}{l}\text { Villanueva-Martínez } \\
\text { et al. [60] }\end{array}$ & 2013 & $21(18 / 11)$ & 73.3 & Types 2 and 3 & $\begin{array}{l}\text { Femoral and } \\
\text { tibial } \\
\text { tantalum } \\
\text { cones } \\
\end{array}$ & 36 & $\begin{array}{l}\text { All metaphyseal cones } \\
\text { showed evidence of stable } \\
\text { osteointegration; good or } \\
\text { excellent results in } 17 \text { cases }\end{array}$ \\
\hline Schmitz et al. [61] & 2013 & 44 & 72 & Types 2 and 3 & $\begin{array}{l}\text { Femoral and } \\
\text { tibial } \\
\text { tantalum } \\
\text { cones }\end{array}$ & 37 & $\begin{array}{l}2 \text { rerevisions for aseptic } \\
\text { loosening; favorable clinical } \\
\text { and radiological outcomes } \\
\text { using tantalum cones in } \\
\text { managing significant bone } \\
\text { losses in revision TKA }\end{array}$ \\
\hline
\end{tabular}


TABLE 4: Continued.

\begin{tabular}{|c|c|c|c|c|c|c|c|}
\hline Author & Year & $\begin{array}{l}\text { Number of cases } \\
\text { (femoral/tibial) }\end{array}$ & $\begin{array}{l}\text { Average } \\
\text { age } \\
(\mathrm{SD})\end{array}$ & $\begin{array}{l}\text { Bone defect } \\
\text { classification } \\
(\text { AORI })\end{array}$ & $\begin{array}{l}\text { Type of } \\
\text { implant }\end{array}$ & $\begin{array}{l}\text { Follow-up } \\
\text { months } \\
(\mathrm{SD})\end{array}$ & Outcomes \\
\hline Rao et al. [62] & 2013 & 29 & 72 & Types 2 and 3 & $\begin{array}{c}\text { Femoral and } \\
\text { tibial } \\
\text { tantalum } \\
\text { cones } \\
\end{array}$ & 36 & $\begin{array}{l}\text { No radiolucent lines; good } \\
\text { osteointegration one year } \\
\text { after surgery; no evidence } \\
\text { of collapse or loosening }\end{array}$ \\
\hline Jensen et al. [67] & 2014 & 36 (all tibial) & 69 & $\begin{array}{c}\text { Types } 2 \text { and } 3 \\
(75 \%)\end{array}$ & $\begin{array}{l}\text { Tantalum } \\
\text { tibial cones }\end{array}$ & 47 & $\begin{array}{l}4 \text { rerevisions ( } 2 \text { infections, } 1 \\
\text { aseptic loosening, } 1 \\
\text { hyperextension); } 27 \\
\text { patients had no radiological } \\
\text { loosening }\end{array}$ \\
\hline Derome et al. [63] & 2014 & 29 & 70 & Types 2 and 3 & $\begin{array}{l}\text { Femoral and } \\
\text { tibial } \\
\text { tantalum } \\
\text { cones }\end{array}$ & 33 & $\begin{array}{l}\text { No evidence of loosening } \\
\text { or migration of the } \\
\text { constructs; no complication }\end{array}$ \\
\hline Boureau et al. [54] & 2015 & 7 (all femoral) & 65 & Types 2 and 3 & $\begin{array}{l}\text { 2-tantalum- } \\
\text { cone } \\
\text { technique }\end{array}$ & 17 & $\begin{array}{l}\text { No complication; no } \\
\text { migration of the femoral } \\
\text { cones }\end{array}$ \\
\hline De Martino et al. [68] & 2015 & $26(13 / 13)$ & 73 & Types 2 and 3 & $\begin{array}{l}\text { Femoral and } \\
\text { tibial } \\
\text { tantalum } \\
\text { cones }\end{array}$ & 72 & $\begin{array}{l}2 \text { reoperations for infection, } \\
\text { but cones were } \\
\text { osteointegrated; no } \\
\text { evidence of loosening; } \\
\text { tantalum cones for } \\
\text { reconstruction of massive } \\
\text { bone defects provided } \\
\text { secure fixation and } \\
\text { outcomes at average } \\
\text { follow-up of } 6 \text { years }\end{array}$ \\
\hline Brown et al. [69] & 2015 & 83 & 69 & $\begin{array}{l}\text { Types } 2 \text { and } 3 \\
\text { (primary and } \\
\text { revision surgery) }\end{array}$ & $\begin{array}{l}\text { Femoral and } \\
\text { tibial } \\
\text { tantalum } \\
\text { cones }\end{array}$ & 40 & $\begin{array}{l}12 \% \text { revision (one aseptic } \\
\text { loosening); of the } \\
\text { unrevised knee, } 99 \% \text { had } \\
\text { complete osteointegration } \\
45 \% \text { experienced at least } \\
\text { one complication }\end{array}$ \\
\hline Kamath et al. [70] & 2015 & 66 & 67 & Types 2 and 3 & $\begin{array}{l}\text { Tibial } \\
\text { tantalum } \\
\text { cones }\end{array}$ & 70 & $\begin{array}{l}\text { Improvement of mean } \\
\text { Knee Society Score; one } \\
\text { patient had progressive } \\
\text { radiolucent line; } 3 \text { cones } \\
\text { were revised: } 1 \text { infection, } 1 \\
\text { aseptic loosening, } 1 \\
\text { periprosthetic fracture; } \\
\text { revision-free survival of the } \\
\text { tibial cone component was } \\
>95 \% \text { at the time of the } \\
\text { latest follow-up }\end{array}$ \\
\hline
\end{tabular}

follow-up; this has to be considered a good outcome in a cohort of patients with a lot of comorbidities and enhances the good integration properties of this material. Recently, Jensen et al. [67] reported their results using tantalum cones to treat major tibial bone losses; at a short-term follow-up only 1 revision for aseptic loosening was necessary, while most of the patients showed well integrated cones. In 2015 three papers with considerable population and midterm follow-up were published. De Martino et al. [68] described their results with 26 (both femoral and tibial) cones at 72 months of follow-up. No evidence of loosening of the cones was detected, and the authors stated that tantalum cones for reconstruction of massive bone defects provided secure fixation and outcomes at average follow-up of 6 years. Brown et al. [69] described one of the biggest populations of femoral and tibial cones at short-term follow-up, reporting a $12 \%$ revision rate, but only one case of aseptic loosening. 99\% of the remaining unrevised knees had complete osteointegration.

Kamath et al. [70] recently reported a midterm followup (70 months) of tibial tantalum cones used to fill major bone defects in revision TKA. The authors described one case of progressive radiolucent line, with a revision-free survival 


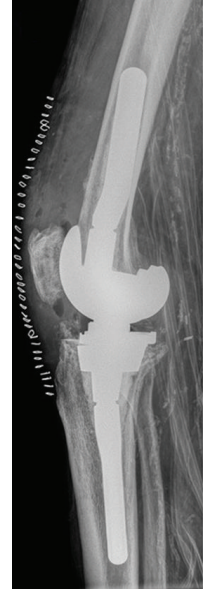

(a)

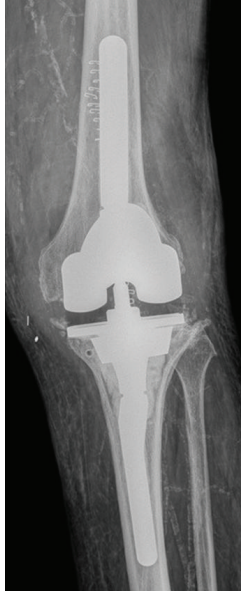

(b)
FIGURE 5: Postoperative X-ray showing (a) lateral view of a revision TKA with a tibial tantalum cone and (b) anteroposterior view of a revision TKA with a tibial tantalum cone.

of the tibial cone component higher than $95 \%$ at the latest follow-up.

Few papers described the result of porous tantalum patellar component in revision TKA $[56,64,65]$. Nasser and Poggie described their results on 11 patients affected by severe patellar bone losses and treated using porous tantalum patellar component. The authors concluded about good clinical and radiological short-term outcomes, with high patients' satisfaction [65]. Kamath et al. in 2012 [56] described their results in 23 patients in which a porous tantalum patellar component was used due to severe patellar bone defects. All patellae had less than $10 \mathrm{~mm}$ residual bone thickness. The survivorship rate was $83 \%$ at the final follow-up.

\section{Conclusion}

The use of tantalum in revision total hip replacement provides a higher integration potential in a shorter time: this helped reducing surgeons' fears when addressing a pelvic discontinuity or big acetabular bone losses. Tantalum provides a good and reliable substitute of bone, even in the very first period after implantation.

Big bone losses can be reduced to normal and easier to handle dimensions, decreasing the surgical challenge; however, in pelvic discontinuity, the problem still can be worrisome. In these cases, tantalum osteoinductive characteristics enhance acetabular ring healing potential, representing a very effective structure and scaffold and providing a good longterm outcome.

In revision total knee replacement, as well as for hips, the osteoinductive potential of tantalum is of paramount importance in the long period, associated with the excellent structural support and defect filling characteristics provided in the first phase after surgery.

In conclusion, tantalum showed to be a very effective material in orthopedic surgery, especially in revision surgery, thanks to the great ductility of the material and its intrinsic characteristics. High porosity, elasticity, bioactivity, biocompatibility, and osteoinductivity are of paramount importance in orthopedic implants and tantalum is actually the state of the art for all these aspects.

\section{Competing Interests}

The authors declare that they have no competing interests.

\section{References}

[1] J. A. Szivek, G. C. Weatherly, R. M. Pilliar, and H. U. Cameron, "A study of bone remodeling using metal-polymer laminates," Journal of Biomedical Materials Research, vol. 15, no. 6, pp. 853865, 1981.

[2] D. M. Findlay, K. Welldon, G. J. Atkins, D. W. Howie, A. C. W. Zannettino, and D. Bobyn, "The proliferation and phenotypic expression of human osteoblasts on tantalum metal," Biomaterials, vol. 25, no. 12, pp. 2215-2227, 2004.

[3] J. D. Bobyn, R. M. Pilliar, H. U. Cameron, and G. C. Weatherly, "The optimum pore size for the fixation of porous surfaced metal implants by the ingrowth of bone," Clinical Orthopaedics and Related Research, vol. 150, pp. 263-270, 1980.

[4] W. J. Gordon, M. G. Conzemius, E. Birdsall et al., "Chondroconductive potential of tantalum trabecular metal," Journal of Biomedical Materials Research Part B: Applied Biomaterials, vol. 75, no. 2, pp. 229-233, 2005.

[5] R. Cohen, "A porous tantalum trabecular metal: basic science," American Journal of Orthopedics, vol. 31, no. 4, pp. 216-217, 2002.

[6] B. R. Levine, S. Sporer, R. A. Poggie, C. J. Della Valle, and J. J. Jacobs, "Experimental and clinical performance of porous tantalum in orthopedic surgery," Biomaterials, vol. 27, no. 27, pp. 4671-4681, 2006.

[7] J. D. Bobyn, G. J. Stackpool, S. A. Hacking, M. Tanzer, and J. J. Krygier, "Characteristics of bone ingrowth and interface mechanics of a new porous tantalum biomaterial," The Journal of Bone \& Joint Surgery-British Volume, vol. 81, no. 5, pp. 907914, 1999.

[8] L. D. Zardiackas, D. E. Parsell, L. D. Dillon, D. W. Mitchell, L. A. Nunnery, and R. Poggie, "Structure, metallurgy, and mechanical properties of a porous tantalum foam," Journal of Biomedical Materials Research, vol. 58, no. 2, pp. 180-187, 2001.

[9] S. A. Hacking, J. D. Bobyn, K.-K. Toh, M. Tanzer, and J. J. Krygier, "Fibrous tissue ingrowth and attachment to porous tantalum," Journal of Biomedical Materials Research, vol. 52, no. 4, pp. 631-638, 2000.

[10] A. Shirazi-Adl, M. Dammak, and G. Paiement, "Experimental determination of friction characteristics at the trabecular bone/porous-coated metal interface in cementless implants," Journal of Biomedical Materials Research, vol. 27, no. 2, pp. 167175, 1992.

[11] J. Black, "Biologic performance of tantalum," Clinical Materials, vol. 16, no. 3, pp. 167-173, 1994.

[12] J. D. Bobyn, K.-K. Toh, S. A. Hacking, M. Tanzer, and J. J. Krygier, "Tissue response to porous tantalum acetabular cups: a canine model," Journal of Arthroplasty, vol. 14, no. 3, pp. 347354, 1999.

[13] H. Matsuno, A. Yokoyama, F. Watari, M. Uo, and T. Kawasaki, "Biocompatibility and osteogenesis of refractory metal 
implants, titanium, hafnium, niobium, tantalum and rhenium," Biomaterials, vol. 22, no. 11, pp. 1253-1262, 2001.

[14] C. B. Johansson, H. A. Hansson, and T. Albrektsson, "Qualitative interfacial study between bone and tantalum, niobium or commercially pure titanium," Biomaterials, vol. 11, no. 4, pp. 277-280, 1990.

[15] S. Kurtz, F. Mowat, K. Ong, N. Chan, E. Lau, and M. Halpern, "Prevalence of primary and revision total hip and knee arthroplasty in the United States from 1990 through 2002," The Journal of Bone \& Joint Surgery-American Volume, vol. 87, no. 7, pp. 1487-1497, 2005.

[16] W. G. Paprosky, S. S. Sporer, and B. P. Murphy, "Addressing severe bone deficiency. What a cage will not do," Journal of Arthroplasty, vol. 22, no. 4, supplement 1, pp. 111-115, 2007.

[17] W. G. Paprosky, P. G. Perona, and J. M. Lawrence, "Acetabular defect classification and surgical reconstruction in revision arthroplasty. A 6-year follow-up evaluation," The Journal of Arthroplasty, vol. 9, no. 1, pp. 33-44, 1994.

[18] E. D. Taylor and J. A. Browne, "Reconstruction options for acetabular revision," World Journal of Orthopaedics, vol. 3, no. 7, pp. 95-100, 2012.

[19] P. F. Lachiewicz and E. S. Soileau, "Tantalum components in difficult acetabular revisions," Clinical Orthopaedics and Related Research, vol. 468, no. 2, pp. 454-458, 2010.

[20] A. Moličnik, M. Hanc, G. Rečnik, Z. Krajnc, M. Rupreht, and S. K. Fokter, "Porous tantalum shells and augments for acetabular cup revisions," European Journal of Orthopaedic Surgery \& Traumatology, vol. 24, no. 6, pp. 911-917, 2014.

[21] A. Siegmeth, C. P. Duncan, B. A. Masri, W. Y. Kim, and D. S. Garbuz, "Modular tantalum augments for acetabular defects in revision hip arthroplasty," Clinical Orthopaedics and Related Research, vol. 467, no. 1, pp. 199-205, 2009.

[22] J. B. Stiehl, "Trabecular metal in hip reconstructive surgery," Orthopedics, vol. 28, no. 7, pp. 662-670, 2005.

[23] B. D. Springer, D. J. Berry, M. E. Cabanela, A. D. Hanssen, and D. G. Lewallen, "Early postoperative transverse pelvic fracture: a new complication related to revision arthroplasty with an uncemented cup," The Journal of Bone \& Joint SurgeryAmerican Volume, vol. 87, no. 12, pp. 2626-2631, 2005.

[24] A. E. Gross and S. B. Goodman, "Rebuilding the skeleton: the intraoperative use of trabecular metal in revision total hip arthroplasty," The Journal of Arthroplasty, vol. 20, no. 4, supplement 2, pp. 91-93, 2005.

[25] W. G. Paprosky, M. O'Rourke, and S. M. Sporer, “The treatment of acetabular bone defects with an associated pelvic discontinuity," Clinical Orthopaedics and Related Research, no. 441, pp. 216-220, 2005.

[26] S. Goodman, H. Saastamoinen, N. Shasha, and A. Gross, "Complications of ilioischial reconstruction rings in revision total hip arthroplasty," Journal of Arthroplasty, vol. 19, no. 4, pp. 436-446, 2004.

[27] J. J. Ballester Alfaro and J. Sueiro Fernandez, “Trabecular Metal buttress augment and the Trabecular Metal cup-cage construct in revision hip arthroplasty for severe acetabular bone loss and pelvic discontinuity," Hip International, vol. 20, supplement 7, pp. S119-S127, 2010.

[28] E. D. Batuyong, H. S. Brock, N. Thiruvengadam, W. J. Maloney, S. B. Goodman, and J. I. Huddleston, "Outcome of porous tantalum acetabular components for paprosky type 3 and 4 acetabular defects," Journal of Arthroplasty, vol. 29, no. 6, pp. 1318-1322, 2014.
[29] S. H. Weeden and R. H. Schmidt, "The use of tantalum porous metal implants for Paprosky 3A and 3B defects," Journal of Arthroplasty, vol. 22, no. 6, supplement 2, pp. 151-155, 2007.

[30] A. Nehme, D. G. Lewallen, and A. D. Hanssen, "Modular porous metal augments for treatment of severe acetabular bone loss during revision hip arthroplasty," Clinical Orthopaedics and Related Research, no. 429, pp. 201-208, 2004.

[31] A. S. Unger, R. J. Lewis, and T. Gruen, "Evaluation of a porous tantalum uncemented acetabular cup in revision total hip arthroplasty: clinical and radiological results of 60 hips," Journal of Arthroplasty, vol. 20, no. 8, pp. 1002-1009, 2005.

[32] S. M. Sporer and W. G. Paprosky, "The use of a trabecular metal acetabular component and trabecular metal augment for severe acetabular defects," Journal of Arthroplasty, vol. 21, no. 6, supplement 2, pp. 83-86, 2006.

[33] S. M. Sporer and W. G. Paprosky, "Acetabular revision using a trabecular metal acetabular component for severe acetabular bone loss associated with a pelvic discontinuity," Journal of Arthroplasty, vol. 21, no. 6, supplement 2, pp. 87-90, 2006.

[34] A. L. Malkani, M. R. Price, C. H. Crawford III, and D. L. Baker, "Acetabular component revision using a porous tantalum biomaterial: a case series," The Journal of Arthroplasty, vol. 24, no. 7, pp. 1068-1073, 2009.

[35] X. Flecher, S. Sporer, and W. Paprosky, "Management of severe bone loss in acetabular revision using a trabecular metal shell," The Journal of Arthroplasty, vol. 23, no. 7, pp. 949-955, 2008.

[36] D. Lakstein, D. Backstein, O. Safir, Y. Kosashvili, and A. E. Gross, "Trabecular Metal ${ }^{\mathrm{TM}}$ cups for acetabular defects with $50 \%$ or less host bone contact," Clinical Orthopaedics and Related Research, vol. 467, no. 9, pp. 2318-2324, 2009.

[37] X. Flecher, W. Paprosky, J.-C. Grillo, J.-M. Aubaniac, and J.N. Argenson, "Do tantalum components provide adequate primary fixation in all acetabular revisions?" Orthopaedics and Traumatology: Surgery and Research, vol. 96, no. 3, pp. 235-241, 2010.

[38] J. H. Davies, G. Y. Laflamme, J. Delisle, and J. Fernandes, "Trabecular metal used for major bone loss in acetabular hip revision," The Journal of Arthroplasty, vol. 26, no. 8, pp. 12451250, 2011.

[39] D. J. Del Gaizo, V. Kancherla, S. M. Sporer, and W. G. Paprosky, "Tantalum augments for paprosky IIIA defects remain stable at midterm followup," Clinical Orthopaedics and Related Research, vol. 470, no. 2, pp. 395-401, 2012.

[40] T. Gehrke, Y. Bangert, B. Schwantes, M. Gebauer, and D. Kendoff, "Acetabular revision in THA using tantalum augments combined with impaction bone grafting," HIP International, vol. 23, no. 4, pp. 359-365, 2013.

[41] R. G. Clement, A. G. Ray, D. J. MacDonald, F. A. Wade, R. Burnett, and M. Moran, "Trabecular metal use in paprosky type 2 and 3 acetabular defects: 5-year follow-up," The Journal of Arthroplasty, vol. 31, no. 4, pp. 863-867, 2016.

[42] J. P. Van Kleunen, G.-C. Lee, P. W. Lementowski, C. L. Nelson, and J. P. Garino, "Acetabular revisions using trabecular metal cups and augments," Journal of Arthroplasty, vol. 24, no. 6, pp. 64-68, 2009.

[43] S. M. Jafari, B. Bender, C. Coyle, J. Parvizi, P. F. Sharkey, and W. J. Hozack, "Do tantalum and titanium cups show similar results in revision hip arthroplasty?" Clinical Orthopaedics and Related Research, vol. 468, no. 2, pp. 459-465, 2010.

[44] M. Fernández-Fairen, A. Murcia, A. Blanco, A. Meroño, A. Murcia, and J. Ballester, "Revision of failed total hip arthroplasty 
acetabular cups to porous tantalum components. A 5-Year Follow-Up Study," Journal of Arthroplasty, vol. 25, no. 6, pp. 865872, 2010.

[45] E. T. Skyttä, A. Eskelinen, P. O. Paavolainen, and V. M. Remes, "Early results of 827 trabecular metal revision shells in acetabular revision," The Journal of Arthroplasty, vol. 26, no. 3, pp. 342345, 2011.

[46] W. J. Long, N. O. Noiseux, T. M. Mabry, A. D. Hanssen, and D. G. Lewallen, "Uncemented porous tantalum acetabular components: early follow-up and failures in 599 revision total hip arthroplasties," The Iowa Orthopaedic Journal, vol. 35, pp. 108-113, 2015.

[47] M. Abolghasemian, S. Tangsaraporn, M. Drexler et al., "The challenge of pelvic discontinuity: cup-cage reconstruction does better than conventional cages in mid-term," Bone and Joint Journal, vol. 96, no. 2, pp. 195-200, 2014.

[48] T. Amenabar, W. A. Rahman, B. M. Hetaimish, P. R. Kuzyk, O. A. Safir, and A. E. Gross, "Promising mid-term results with a cup-cage construct for large acetabular defects and pelvic discontinuity," Clinical Orthopaedics and Related Research, vol. 474, no. 2, pp. 408-414, 2016.

[49] G. A. Engh and D. J. Ammeen, "Classification and preoperative radiographic evaluation: knee," Orthopedic Clinics of North America, vol. 29, no. 2, pp. 205-217, 1998.

[50] M. Vasso, P. Beaufils, S. Cerciello, and A. Schiavone Panni, "Bone loss following knee arthroplasty: potential treatment options," Archives of Orthopaedic and Trauma Surgery, vol. 134, no. 4, pp. 543-553, 2014.

[51] C. S. Radnay and G. R. Scuderi, "Management of bone loss: augments, cones, offset stems," Clinical Orthopaedics and Related Research, vol. 446, pp. 83-92, 2006.

[52] R. Morgan-Jones, S. I. S. Oussedik, H. Graichen, and F. S. Haddad, "Zonal fixation in revision total knee arthroplasty," Bone and Joint Journal B, vol. 97, no. 2, pp. 147-149, 2015.

[53] J. M. Cuckler, "Bone loss in total knee arthroplasty: graft augment and options," The Journal of Arthroplasty, vol. 19, no. 4, supplement 1, pp. 56-58, 2004.

[54] F. Boureau, S. Putman, A. Arnould, G. Dereudre, H. Migaud, and G. Pasquier, "Tantalum cones and bone defects in revision total knee arthroplasty," Orthopaedics and Traumatology: Surgery and Research, vol. 101, no. 2, pp. 251-255, 2015.

[55] N. A. Beckmann, S. Mueller, M. Gondan, S. Jaeger, T. Reiner, and R. G. Bitsch, "Treatment of severe bone defects during revision total knee arthroplasty with structural allografts and porous metal cones-a systematic review," Journal of Arthroplasty, vol. 30, no. 2, pp. 249-253, 2015.

[56] A. F. Kamath, A. O. Gee, C. L. Nelson, J. P. Garino, P. A. Lotke, and G.-C. Lee, "Porous tantalum patellar components in revision total knee arthroplasty. Minimum 5-year follow-up," The Journal of Arthroplasty, vol. 27, no. 1, pp. 82-87, 2012.

[57] R. M. Meneghini, D. G. Lewallen, and A. D. Hanssen, "Use of porous tantalum metaphyseal cones for severe tibial bone loss during revision total knee replacement," The Journal of Bone \& Joint Surgery-American Volume, vol. 90, no. 1, pp. 78-84, 2008.

[58] W. J. Long and G. R. Scuderi, "Porous tantalum cones for large metaphyseal tibial defects in revision total knee arthroplasty: a minimum 2-year follow-up," Journal of Arthroplasty, vol. 24, no. 7, pp. 1086-1092, 2009.

[59] P. F. Lachiewicz, M. P. Bolognesi, R. A. Henderson, E. S. Soileau, and T. P. Vail, "Can tantalum cones provide fixation in complex revision knee arthroplasty?" Clinical Orthopaedics and Related Research, vol. 470, no. 1, pp. 199-204, 2012.
[60] M. Villanueva-Martínez, B. De la Torre-Escudero, J. M. RojoManaute, A. Ríos-Luna, and F. Chana-Rodriguez, "Tantalum cones in revision total knee arthroplasty. A promising shortterm result with 29 cones in 21 patients," Journal of Arthroplasty, vol. 28, no. 6, pp. 988-993, 2013.

[61] H.-C. R. Schmitz, W. Klauser, M. Citak, H. Al-Khateeb, T. Gehrke, and D. Kendoff, "Three-year follow up utilizing tantal cones in revision total knee arthroplasty," Journal of Arthroplasty, vol. 28, no. 9, pp. 1556-1560, 2013.

[62] B. M. Rao, T. T. Kamal, J. Vafaye, and M. Moss, "Tantalum cones for major osteolysis in revision knee replacement," Bone and Joint Journal, vol. 95, no. 8, pp. 1069-1074, 2013.

[63] P. Derome, A. Sternheim, D. Backstein, and M. Malo, “Treatment of large bone defects with trabecular metal cones in revision total knee arthroplasty: short term clinical and radiographic outcomes," Journal of Arthroplasty, vol. 29, no. 1, pp. 122-126, 2014.

[64] C. L. Nelson, J. H. Lonner, A. Lahiji, J. Kim, and P. A. Lotke, "Use of a trabecular metal patella for marked patella bone loss during revision total knee arthroplasty," The Journal of Arthroplasty, vol. 18, no. 7, supplement 1, pp. 37-41, 2003.

[65] S. Nasser and R. A. Poggie, "Revision and salvage patellar arthroplasty using a porous tantalum implant," Journal of Arthroplasty, vol. 19, no. 5, pp. 562-572, 2004.

[66] J. L. Howard, J. Kudera, D. G. Lewallen, and A. D. Hanssen, "Early results of the use of tantalum femoral cones for revision total knee arthroplasty," Journal of Bone and Joint SurgerySeries A, vol. 93, no. 5, pp. 478-484, 2011.

[67] C. L. Jensen, N. Winther, H. M. Schrøder, and M. M. Petersen, "Outcome of revision total knee arthroplasty with the use of trabecular metal cone for reconstruction of severe bone loss at the proximal tibia," Knee, vol. 21, no. 6, pp. 1233-1237, 2014.

[68] I. De Martino, V. De Santis, P. K. Sculco, R. D’Apolito, J. B. Assini, and G. Gasparini, "Tantalum cones provide durable mid-term fixation in revision TKA," Clinical Orthopaedics and Related Research, vol. 473, no. 10, pp. 3176-3182, 2015.

[69] N. M. Brown, J. A. Bell, E. K. Jung, S. M. Sporer, W. G. Paprosky, and B. R. Levine, "The use of trabecular metal cones in complex primary and revision total knee arthroplasty," Journal of Arthroplasty, vol. 30, no. 9, suppleme, pp. 90-93, 2015.

[70] A. F. Kamath, D. G. Lewallen, and A. D. Hanssen, "Porous tantalum metaphyseal cones for severe tibial bone loss in revision knee arthroplasty: a five to nine-year follow-up," The Journal of Bone \& Joint Surgery - American Volume, vol. 97, no. 3, pp. 216-223, 2015. 

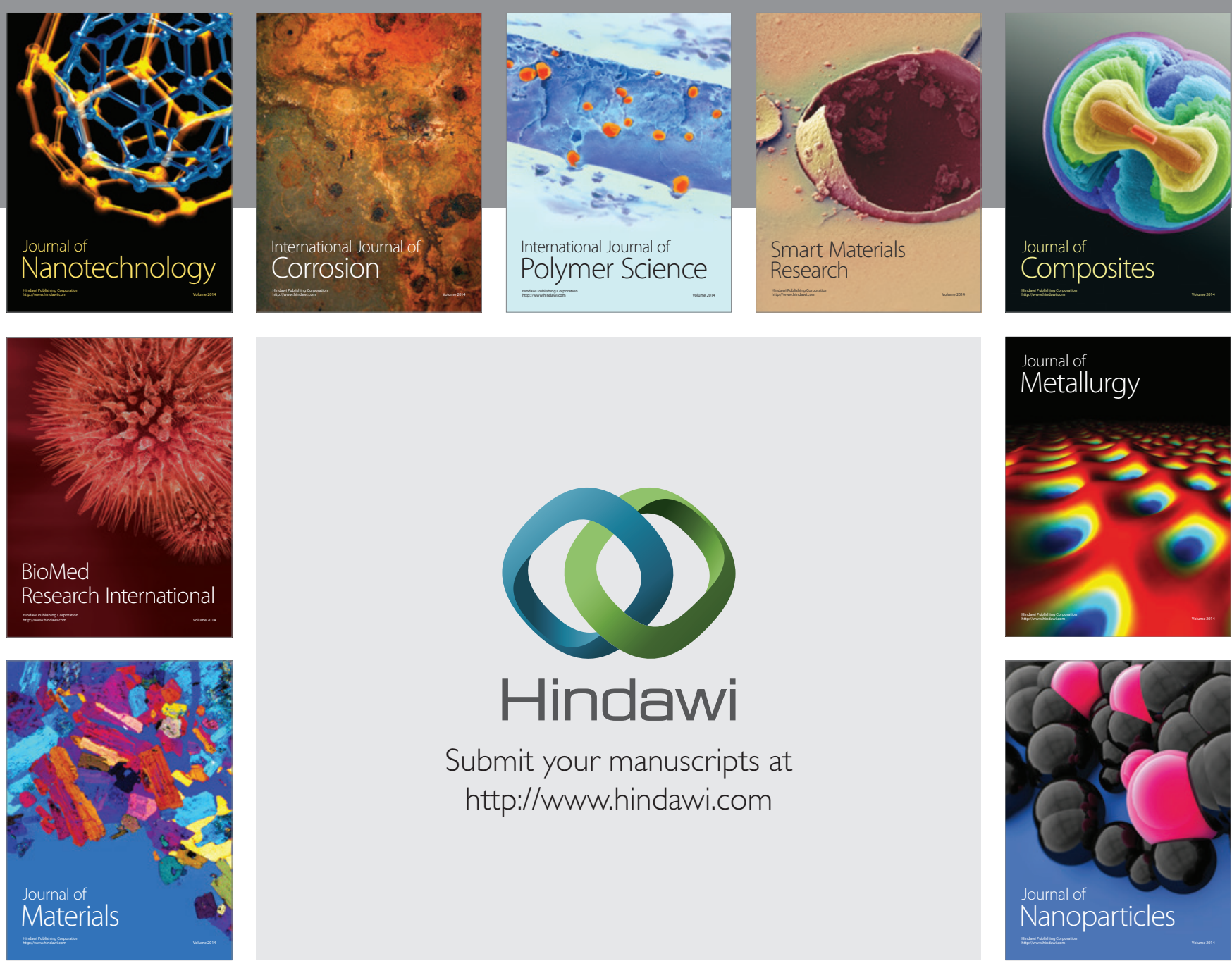

\section{Hindawi}

Submit your manuscripts at

http://www.hindawi.com

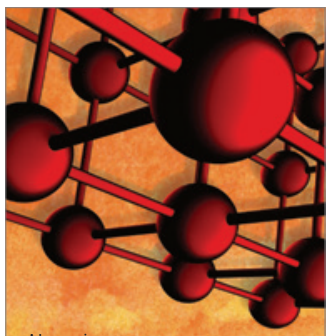

Materials Science and Engineering
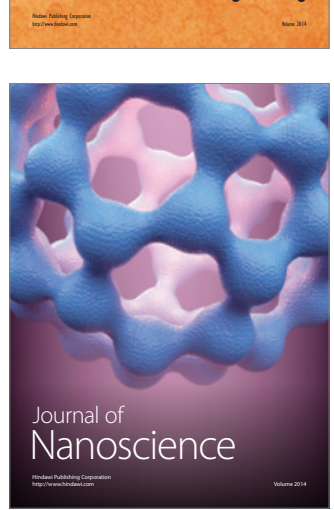
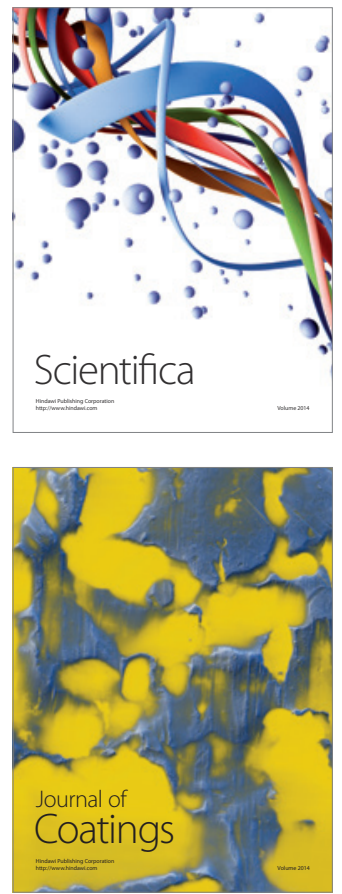
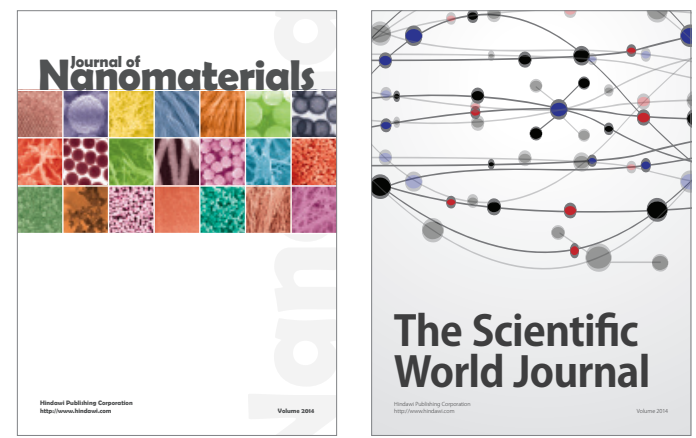

The Scientific World Journal
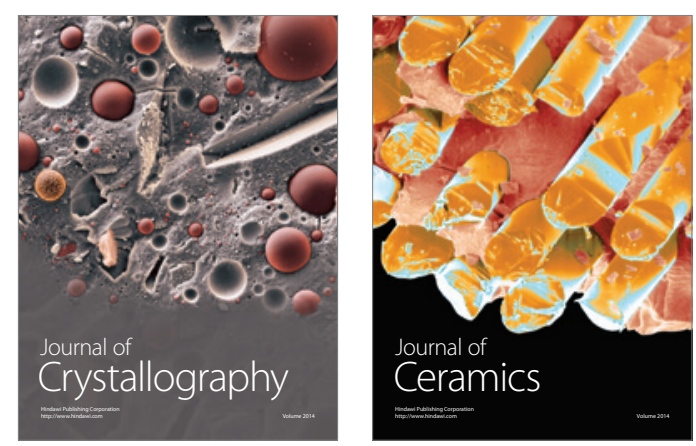
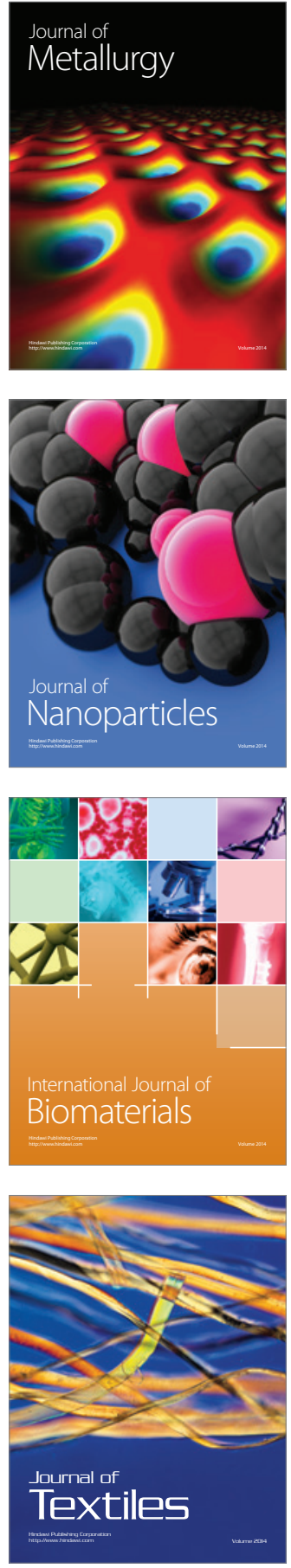